\title{
Het lijden dat men vreest
}

Citation for published version (APA):

Peters, M. L., \& Vlaeyen, J. W. S. (2010). Het lijden dat men vreest. In A. T. M. Jansen, M. V. D. Hout, \& H. L. G. J. Merckelbach (Eds.), Gek. Experimentele psychopathologie (pp. 175-190). Bohn Stafleu van Loghum. https://doi.org/10.1007/978-90-313-7640-7_11

Document status and date:

Published: 01/01/2010

DOI:

10.1007/978-90-313-7640-7_11

Document Version:

Publisher's PDF, also known as Version of record

Document license:
Taverne

Please check the document version of this publication:

- A submitted manuscript is the version of the article upon submission and before peer-review. There can be important differences between the submitted version and the official published version of record.

People interested in the research are advised to contact the author for the final version of the publication, or visit the DOI to the publisher's website.

- The final author version and the galley proof are versions of the publication after peer review.

- The final published version features the final layout of the paper including the volume, issue and page numbers.

Link to publication

\footnotetext{
General rights rights.

- You may freely distribute the URL identifying the publication in the public portal. please follow below link for the End User Agreement:

www.umlib.nl/taverne-license

Take down policy

If you believe that this document breaches copyright please contact us at:

repository@maastrichtuniversity.nl

providing details and we will investigate your claim.
}

Copyright and moral rights for the publications made accessible in the public portal are retained by the authors and/or other copyright owners and it is a condition of accessing publications that users recognise and abide by the legal requirements associated with these

- Users may download and print one copy of any publication from the public portal for the purpose of private study or research.

- You may not further distribute the material or use it for any profit-making activity or commercial gain

If the publication is distributed under the terms of Article $25 \mathrm{fa}$ of the Dutch Copyright Act, indicated by the "Taverne" license above, 


\section{Het lijden dat men vreest}

Pijn

Een bouwvakker loopt in stevige pas over de bouwplaats. Per ongeluk stapt hij met zijn volle gewicht op een plank waaruit een enorme spijker omhoogsteekt. Tot zijn ontzetting ziet de bouwvakker de spijker door de zool van zijn schoen heen boren, en door de schoen zelf, om er aan de bovenkant bij de tenen weer uit te komen. Hij schreeuwt het uit van de pijn. Gealarmeerd komen collega's toegesneld en zij brengen hem zo snel mogelijk naar de spoedeisende hulp van het ziekenhuis. Onder angstige pijnkreten van het slachtoffer knipt de dienstdoende arts de schoen open om de spijker te kunnen verwijderen. Dan volgt de verrassing. De spijker heeft zich tussen twee tenen door geboord. Alleen de schoen is beschadigd, de voet is ongeschonden.

Henry Beecher diende gedurende de Tweede Wereldoorlog als arts in het leger en zag daar vele zwaargewonde soldaten. Het viel hem op dat deze soldaten nauwelijks over pijn klaagden, ook niet als ze urenlang geen pijnmedicatie kregen. Dit in groot contrast tot de pijnklachten die hij gewend was te horen van zijn patiënten in het Massachusetts General Hospital die vergelijkbare verwondingen opliepen, en bovendien veel meer pijnmedicatie kregen (Beecher, 1946). Beecher speculeerde dat de pijn van de soldaten verzacht werd door de wetenschap dat zij het slagveld hadden overleefd en er een periode van veiligheid in het vooruitzicht lag. Voor de patiënten betekende de pijn juist het verlies van de veilige thuisomgeving. 
Deze twee anekdotes illustreren dat pijn geen een-op-eenrelatie heeft met de ernst van de onderliggende weefselschade. Bij ernstige verwondingen is het mogelijk dat er slechts een minimale pijnervaring is, terwijl mensen ook pijn kunnen voelen zonder dat er sprake van weefselschade is. Zoals uit bovenstaande voorbeelden duidelijk wordt, spelen emotionele factoren, verwachtingen, en de betekenis die de pijn heeft een belangrijke rol bij de uiteindelijke ervaring van pijn. Dit hoofdstuk gaat over psychologische factoren die pijnervaring en pijngedrag beïnvloeden. Maar eerst wat meer informatie over de functie van pijn en de biologische achtergrond van de pijnervaring.

\section{Wat is pijn?}

Het klinkt paradoxaal, maar het lijden van pijn levert wellicht de beste bescherming voor overleving. Door pijn leren we het verschil tussen schadelijke en niet-schadelijke situaties. Pijn dwingt tot vlucht- en vermijdingsgedrag, en tot het onderdrukken van andere activiteiten om genezing van een verwonding mogelijk te maken (Wall, 1979). Hoe werkt pijn? Neem een snijwond. Door de wond komen de neurotransmitters histamine en bradykinine vrij en die zorgen voor prikkeling van de A-delta- en C-zenuwvezels. Daardoor ontstaat er een elektrisch signaal. Dit signaal wordt doorgestuurd naar het ruggenmerg, waar onder invloed van andere neurotransmitters een nieuw elektrisch signaal aan de hersenen wordt doorgegeven (bottom-up). Pas nadat het pijnsignaal de thalamus heeft bereikt wordt een persoon zich bewust van de pijn. De thalamus is met veel andere hersengebieden verbonden, zoals de insula en de somatosensorische hersenschors. Activiteit in dit gebied maakt het mogelijk dat iemand kan onderscheiden met welke soort pijn hij te maken heeft (bijvoorbeeld snijdend) en waar het pijnsignaal vandaan komt (bijvoorbeeld de rechtervoet). Daarnaast bestaan er connecties met het limbisch systeem, meer in het bijzonder de anterieure cingulaire cortex (ACC), die een belangrijke rol speelt in de affectieve dimensie van pijn. Ten slotte is er de prefrontale cortex die verantwoordelijk is voor de cognitieve aspecten: de organisatie, controle en het onderdrukken van pijngedrag. Figuur II.I is een grafische voorstelling van de zenuwbanen en projectiegebieden die een rol spelen bij pijn.

Naast opstijgende banen zijn er afdalende pijnbanen van de hersenen naar het ruggenmerg toe (top-down). Deze hebben een pijnmodulerende werking: zij kunnen pijn versterken of afzwakken. Opvallend is dat voornamelijk de hersengebieden die een functie hebben in emotieverwerking een modulerende invloed hebben op de pijnverwerking, zoals het periaqueductale grijs, de amygdala, de hypothalamus en 


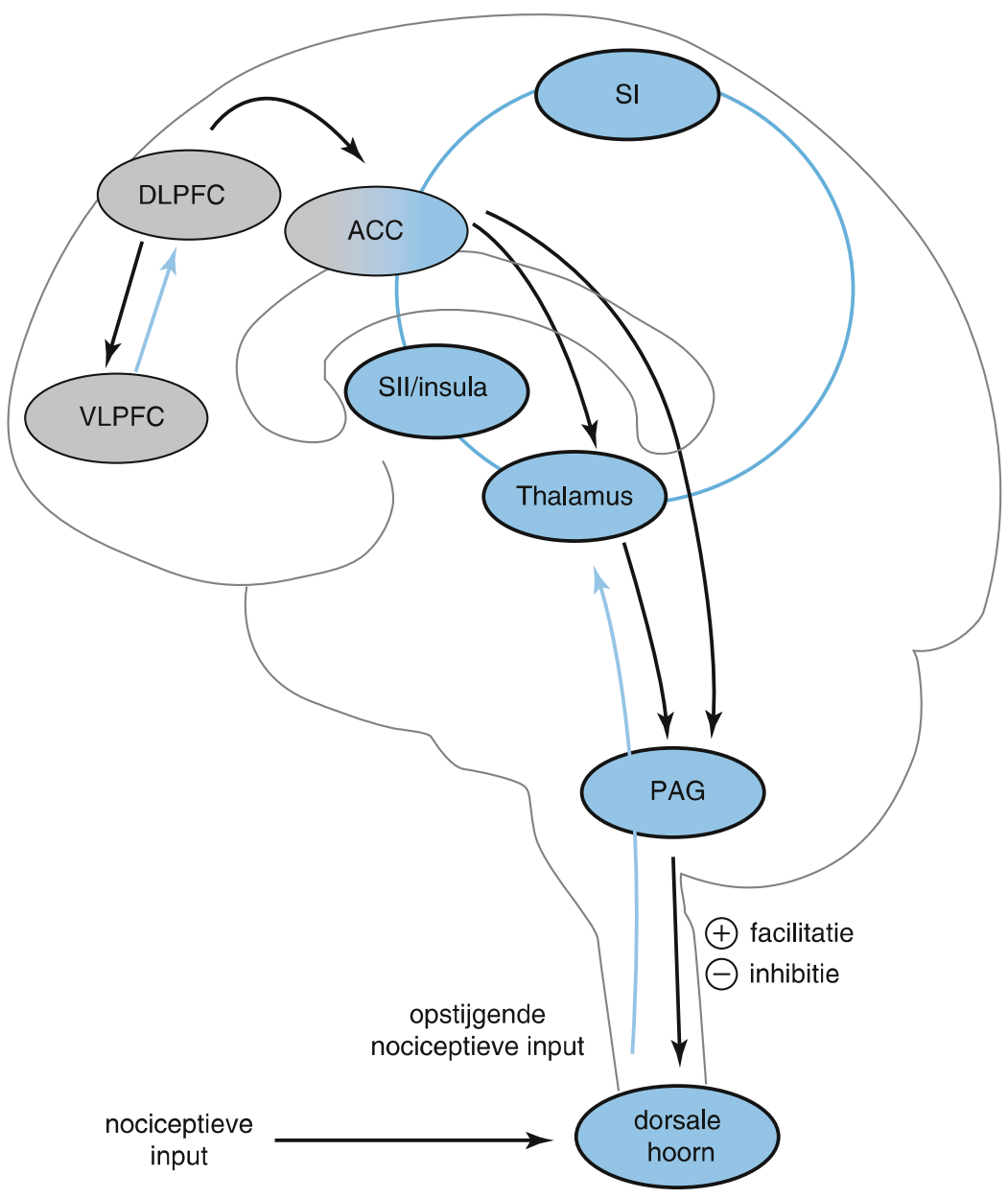

Figuur 11.1 Schematische voorstelling van de zenuwbanen die een rol spelen bij pijn. $A C C=$ anterieure cingulaire cortex; $D L P F C=$ dorsolaterale prefrontale cortex; VLPFC = ventrolaterale prefrontale cortex; $\mathrm{SI}=$ primaire somatosensorische cortex; SII/Insula = secundaire somatosensorische cortex/insula; PAG $=$ periaqueductaal grijs. De cirkel verbindt de aan pijn gerelateerde gebieden in de cortex (Thalamus, ACC, SI, SII en Insula). De aanduidingen +1 - in de figuur geven aan, dat facilitatie en inhibitie van pijnprocessen plaatsvinden ter hoogte van de dorsale hoorn in het ruggenmerg

de ACC. Dit zijn gebieden waar enkefaline wordt aangemaakt, een lichaamseigen soort opium dat de bottum-upinformatie van pijnprikkels tegenhoudt. Volgens de invloedrijke poorttheorie (gate control theory) van pijn vindt in het ruggenmerg een weging plaats tussen de opstijgende en afdalende informatie (Melzack \& Wall, I965). De resultante van deze weging bepaalt de pijn die uiteindelijk ervaren wordt. Belangrijke pijnmodulerende top-downprocessen zijn onder meer verwachtingen en emoties. 
Het is belangrijk om onderscheid te maken tussen 'nociceptie' en pijn. Nociceptie is de (niet-bewuste) activiteit van pijnreceptoren, zenuwbanen, het ruggenmerg en het brein, veroorzaakt door een schadelijke stimulus. Pijn is een bewuste ervaring, die doorgaans het gevolg is van nociceptieve activiteit, maar niet altijd. De bouwvakker met die enorme spijker tussen zijn ongeschonden tenen is een mooi voorbeeld van pijn zonder nociceptie. Er kan ook nociceptieve prikkeling zijn zonder pijn. Een aansprekend voorbeeld is het volledig blokkeren van de bewuste pijnervaring tijdens een operatieve ingreep door middel van hypnotische suggestie. Intrigerend is ook de Indiase religieuze rite 'Bagad': jongemannen zegenen de oogst terwijl ze aan metalen haken hangen die in het vlees van hun rug en borst bevestigd zijn. Ondanks een hoogstwaarschijnlijk formidabele nociceptieve input, vertonen de jongeheren doorgaans nauwelijks tekenen van pijn. Waarom? Waarschijnlijk omdat deelname aan deze rite voor de uitverkorenen grote betekenis heeft. Net als voor de soldaten van Henry Beecher zijn voor de Indiase jongemannen aan de vleeshaken verwonding en pijn verbonden met een positieve uitkomst: voor de soldaten ontsnapping aan het oorlogsgeweld, voor de jongelingen nogal wat aanzien, en voor hun familie een flinke toename van de sociale status.

De mate van bewuste pijnervaring laat zich dus niet rechtstreeks afleiden uit de sterkte van de nociceptieve prikkeling. Emoties (zoals angst) en cognities (zoals de betekenis van de pijn) hebben een niet te onderschatten invloed op het uiteindelijke lijden. Maar we hebben dit hierboven uitsluitend geïllustreerd aan de hand van anekdotes en klinische observaties. Dat is geen onomstotelijk wetenschappelijk bewijs. Nu de experimenten.

\section{Het hete ijsstokje}

Een prikkel die schadelijk wordt gevonden, ervaren mensen gewoonlijk als intenser en onplezieriger dan eenzelfde prikkel die men onschadelijk vindt. Een elegante demonstratie van deze stelling werd geleverd door Arntz en Claassens (2004). Het idee voor het experiment is terug te voeren op een trucje dat onderzoeker Arntz in zijn jeugd had gelezen. Het beschrijft hoe je iemand de stuipen op het lijf kunt jagen door een ijsstokje in zijn nek te leggen en te suggereren dat het om een brandende sigaret gaat. Want: ijskoude en hete prikkels zijn moeilijk van elkaar te onderscheiden als je ze kort voelt en niet ziet. Het slachtoffer van de truc zal door de suggestie dat het om een sigaret gaat de koudeprikkel in zijn nek als heet - en potentieel schadelijk - interpreteren. Deze truc werd in een wetenschappelijk jasje gestoken om te testen of de vermeende schadelijkheid van een prikkel inderdaad in- 
vloed heeft op de ervaren intensiteit. De achterliggende gedachte was dat de meeste mensen hitte als meer schadelijk zien dan koude (Arntz \& Claassens, 2004).

Een metalen staafje werd afgekoeld tot $-25^{\circ} \mathrm{C}$ en vervolgens gedurende 2 seconden in de nek gelegd van een gezonde vrijwilliger, buiten diens gezichtsveld. Voordat het staafje in de nek werd gelegd, zei de proefleider tegen de helft van de proefpersonen 'dit is heel heet', tegen de andere helft zei hij 'dit is heel koud'. De proefpersonen beoordeelden de prikkel op een aantal verschillende aspecten, zoals temperatuur, intensiteit van de pijn en schadelijkheid. Dertien van de 15 proefpersonen die de 'hete' prikkel kregen, voelden hem ook als heet, terwijl dat in de koudeconditie voor slechts drie proefpersonen het geval was. Belangrijker echter was dat de proefpersonen in de heteprikkelconditie de prikkel ook schadelijker én pijnlijker vonden dan die in de koudeprikkelconditie.

In een vervolgstudie kreeg elke deelnemer 32 prikkels toegediend op de hand. De proefpersonen werd verteld dat een rood lampje aangaf dat de prikkel warm was ( $\mathrm{I} 6 \mathrm{x}$ ) terwijl een blauw lampje aangaf dat de prikkel koud was (I6x). In werkelijkheid was de prikkel telkens identiek: een ijskoude prikkel van $-20^{\circ} \mathrm{C}$ gedurende $500 \mathrm{msec}$ (Moseley \& Arntz, 2007). Wederom was er een sterk effect van de suggestie over de aard van de prikkel. 'Warme' prikkels werden als warmer, onplezieriger en pijnlijker ervaren dan 'koude' prikkels (zie figuur II.2).

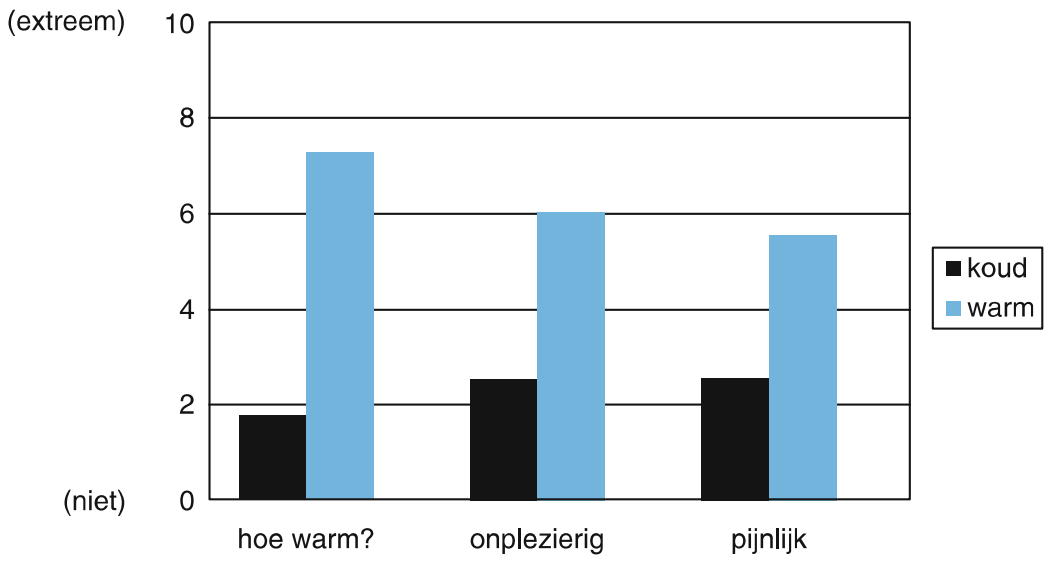

Figuur 11.2 De inschatting van warmte, onplezierigheid en pijnlijkheid van identieke prikkels hangt af van de suggestie of de (identieke) prikkel warm of koud is. Gebaseerd op Moseley en Arntz (2007)

De ingeschatte schadelijkheid van een pijnprikkel beïnvloedt ook hoe lang iemand een pijnprikkel wenst te verdragen. Friedman en collega's 
(Friedman, Thompson, \& Rosen, 1985) lieten gezonde studenten hun hand onderdompelen in ijswater. Na enige tijd leidt dit tot een pijnlijke sensatie in de hand, die naarmate de tijd verstrijkt steeds sterker wordt. Deelnemers die voor aanvang van de pijntest geïnformeerd waren over de aard van de sensaties die hen te wachten stonden, en daarbij te horen kregen dat deze sensaties tijdelijk en onschadelijk waren, hielden hun hand meer dan twee keer zo lang onder water (42I sec.) dan deelnemers die geen informatie kregen (I79 sec.).

\section{De elektrische schok}

Wie (meer) pijn verwacht, ervaart vervolgens ook (meer) pijn. In een grootschalig experiment suggereerden Colloca en collega's dat de pijnlijkheid van een elektrische prikkel zou toenemen. Deze verwachting leidde ertoe dat de prikkel ook daadwerkelijk als steeds pijnlijker werd ervaren (Colloca, Sigaudo, \& Benedetti, 2008). Voor elke deelnemer werd bij aanvang van het experiment de pijndrempel voor een elektrische schok op de rug van de hand bepaald. Vervolgens kreeg een deel van de groep de verbale suggestie dat de schok pijnlijker zou gaan worden. In werkelijkheid bleef de prikkel ongewijzigd. Na de suggestie werd ook een elektrische schok die onder de daarvoor vastgestelde pijndrempel lag ineens pijnlijk. En een schok die een heel klein beetje boven de pijndrempel lag werd als zeer pijnlijk ingeschat. In de controlegroep - die geen suggestie over toename van pijn had gekregen - deden de schokken steeds evenveel pijn.

Verwachtingen van pijn beïnvloeden niet alleen de verbale pijnrapportage, ook de activiteit in nociceptieve gebieden in de hersenen verandert (Keltner et al., 2006; Koyama, McHaffie, Laurienti, \& Coghill, 2005; Lorenz et al., 2005). Keltner en collega's (2006) gaven 27 gezonde vrijwilligers in totaal 40 pijnprikkels terwijl ze in een scanner lagen. Twintig prikkels hadden een hoge intensiteit en 20 prikkels een lage. Elke prikkel werd voorafgegaan door een visueel signaal dat aangaf of de proefpersoon een sterke of een zwakke pijnprikkel kon verwachten. In de helft van de gevallen was het signaal correct, in de andere helft niet. Zo werden er dus 4 condities gecreëerd, elk goed voor Io pijnprikkels: (I) verwachting zwakke prikkel \& feitelijk zwakke prikkel; (2) verwachting sterke prikkel \& feitelijk zwakke prikkel; (3) verwachting sterke prikkel \& feitelijk sterke prikkel; (4) verwachting zwakke prikkel \& feitelijk sterke prikkel. In onderstaande figuur wordt per conditie de gemiddeld ervaren pijnintensiteit (Io-puntsschaal) weergegeven. Sterke prikkels werden als meer pijnlijk ervaren dan zwakke prikkels, maar onafhankelijk daarvan was er een significant effect van de op- 
geroepen verwachting. De pijnlijkheid van zwakke prikkels nam toe als de deelnemer verwachtte dat de prikkel sterk zou zijn. Omgekeerd nam de pijnlijkheid van een sterke prikkel af als er een zwakke prikkel werd verwacht (zie figuur II.3).

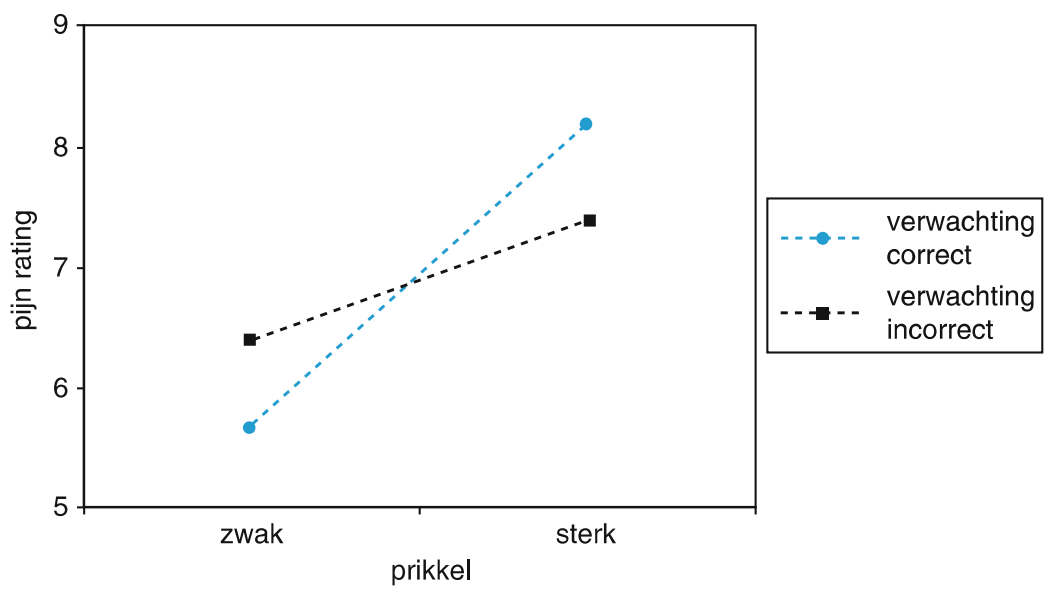

Figuur 11.3 De verwachting dat er een sterke prikkel zal komen vergroot de pijnlijkheid van een zwakke prikkel. Omgekeerd, als een zwakke prikkel wordt verwacht, wordt een sterke prikkel als minder pijnlijk ervaren

Analyse van de gegevens van de Functional Magnetic Resonance Imaging (fMRI) liet zien dat verwachtingen ook invloed hebben op de activiteit in hersengebieden die pijn verwerken. De grootste activiteit werd gemeten wanneer de deelnemers een sterke pijnprikkel verwachtten en deze ook daadwerkelijk kregen. Dit suggereert dat de verwachting van intense pijn de daadwerkelijke nociceptieve input kan versterken. Hetzelfde onderzoek leverde ook bewijs voor de veronderstelling dat de versterking of afzwakking van activiteit in de voor pijn relevante hersengebieden door verwachtingen veroorzaakt wordt door afdalende zenuwverbindingen naar het ruggenmerg. Inderdaad, wanneer de nociceptieve input op ruggenmergniveau versterkt of verzwakt wordt, bereikt uiteindelijk meer of minder nociceptieve activiteit de hersenen.

\section{Placebo en nocebo}

Heeft het induceren van verwachtingen ook effect op klinische pijn? Het verschijnsel placebo-analgesie is wel bekend: alleen al de verwachting dat een bepaald medicament of behandeling pijnverlichting zal geven, kan tot een daadwerkelijke afname van pijn leiden. Recent onderzoek laat zien dat placeboanalgesie in een klinische steekproef 
eveneens gepaard gaat met verminderde activiteit in pijnrelevante hersengebieden (Price, Craggs, Nicholas Verne, Perlstein, \& Robinson, 2007). De tegenhanger van het placebo-effect is het zogenaamde 'nocebo-effect', waarbij de suggestie wordt gewekt dat een bepaalde handeling of ingreep een toename in pijn zal veroorzaken. Dat nocebosuggestie kan leiden tot een significante toename in klinische pijn werd gedemonstreerd in een studie van Benedetti en collega's (Benedetti, Amanzio, Casadio, Oliaro, \& Maggi, 1997). Patiënten die een kijkoperatie hadden ondergaan kregen een niet-werkzaam middel toegediend vergezeld van de suggestie dat dit tijdelijk hun postoperatieve pijn zou verhogen. De patiënten in de noceboconditie rapporteerden daadwerkelijk meer pijn dan patiënten in de controleconditie. Gezien de eerder beschreven bevinding dat nocebosuggesties sterker zijn dan placebosuggesties kan dit belangrijke klinische implicaties hebben (Colloca et al., 2008). De expliciete suggesties van een behandelaar, maar ook impliciete suggesties zoals die tot uiting komen in zijn attitude, kunnen leiden tot een verergering van symptomen.

Dat verwachtingen over pijn de rapportage van pijn beïnvloeden is betekenisvol, maar veranderen ze ook gedrag? Als overschatting van pijn leidt tot (onnodige) vermijding van de pijnlijke prikkel, dan kan dit ervoor zorgen dat de patiënt in een negatieve spiraal terechtkomt van een steeds slechter wordende lichamelijke conditie en toenemende beperkingen. McCracken en collega's (McCracken, Gross, Sorg, \& Edmands, 1993) vroegen aan patiënten met chronische rugpijn - terwijl ze op hun rug lagen - het gestrekte been te heffen, tot de pijntolerantie voor die beweging was bereikt. Deze beweging werd 6 keer herhaald, 3 keer voor elk been. Voorafgaande aan elke beweging scoorde de patiënt hoeveel pijn werd verwacht, en na de beweging hoeveel pijn daadwerkelijk werd ervaren. De bereikte heffingshoek bleek sterker bepaald door de verwachte pijn dan door de feitelijk ervaren pijn. Pfingsten en collega's (2002) gingen een stap verder. Zij manipuleerden de pijnverwachting. Het waren patiënten met chronische rugklachten die deelnamen aan een experiment waarin ze het onderbeen moesten strekken en buigen tegen een (individueel vastgestelde) weerstand. De controlegroep kreeg te horen dat de test geen invloed op hun rugpijn zou hebben, de experimentele groep dat de test een tijdelijke toename in rugpijn zou veroorzaken. Het aantal bewegingen, de bewegingsuitslag in graden en de totale arbeid werden bepaald. De suggestie dat de test tot pijn zou leiden, resulteerde in minder buigingen, een kleinere bewegingsuitslag en minder totale arbeid vergeleken met de controleinstructie. Omdat patiënten volgens toeval aan de condities waren toegewezen en de verwachtingen experimenteel werden gewekt, vor- 
men deze bevindingen een aanwijzing dat de verwachting van pijn een oorzaak is van de vermijding van lichamelijke inspanning (Pfingsten et al., 2002). Een overschatting van pijn kan zichzelf bovendien in stand houden. Door vermijding worden verwachtingen niet meer getoetst aan de werkelijkheid, waardoor de overschatting van toekomstige pijn blijft voortbestaan (Arntz, Van Eck, \& Heijmans, 1990; Philips, 1987). Pas als patiënten leren hun vermijding te overwinnen en ervaren dat de verwachte pijntoename uitblijft, kan bijstelling van de overschatting plaatsvinden. Deze bevindingen hadden grote invloed op de behandeling van patiënten met chronische pijn. Daarover later meer.

\section{Pijn catastroferen}

Tot nu toe is vooral aandacht geschonken aan contextuele variabelen die verwachtingen over en betekenis van pijn kunnen bepalen. Maar ook individuele verschillen spelen een rol. Sommige mensen zijn meer geneigd om een negatieve betekenis toe te kennen aan pijn, of om in een bepaalde situatie eerder te verwachten dat iets pijnlijk zal zijn dan anderen. Een extreme neiging om een negatieve betekenis aan pijn toe te kennen noemen we 'pijn catastroferen'.

Er is ruime evidentie dat het catastroferen van pijn een belangrijke rol speelt in het omgaan met pijn (voor overzichtsartikelen zie: Keefe, Rumble, Scipio, Giordano, \& Perri, 2004; Quartana, Campbell, \& Edwards, 2009; Sullivan et al., 200I). Gezonde personen met een relatief hogere score op catastroferen rapporteren gemiddeld meer pijn dan personen die niet catastroferen wanneer er een gestandaardiseerde pijnprikkel wordt aangeboden, en ze hebben een lagere pijndrempel en pijntolerantie (Edwards, Fillingim, Maixner, Sigurdsson, \& Haythornthwaite, 2004; Thorn, Keefe, \& Anderson, 2004, Weissman-Fogel, Sprecher, \& Pud, 2008). Ook in de fMRI-scanner zijn er verschillen te ontdekken: catastroferen hangt positief samen met activiteit in hersengebieden die te maken hebben met de aandacht voor pijn, de emotionele verwerking van pijn, en de motorische reactie op pijn. Verder is er een negatieve samenhang met neuronale activiteit in gebieden die te maken hebben met de top-downcontrole van pijn (Gracely et al., 2004; Seminowicz \& Davis, 2006).

\section{Angst voor de pijn}

Nauw verwant met pijn catastroferen is angst voor pijn, en angst om verdere schade aan het lichaam op te lopen. Een van de meest invloedrijke modellen voor het verklaren van chronische pijnklachten aan het 
bewegingsapparaat is het zogenaamde vreesvermijdingsmodel (Leeuw et al., 2007; Lethem, Slade, Troup, \& Bentley, I983; Vlaeyen, Kole-Snijders, Boeren, \& Van Eek, I995; Vlaeyen \& Linton, 2000). Het uitgangspunt van dit model is dat de interpretatie van pijn, en de betekenistoekenning aan pijn, leiden tot twee mogelijke uitkomsten. Iemand die acute pijn als een weliswaar hinderlijke maar niet bedreigende gebeurtenis ziet, herneemt spoedig de dagelijkse activiteiten, met spoedig herstel tot gevolg. Indien dezelfde pijnervaring echter als bedreigend wordt ervaren, kan dit aanleiding geven tot angst voor pijn en vermijding van lichamelijke activiteiten. Bij langdurige vermijding kunnen mensen in een negatieve spiraal terechtkomen, waarbij inactiviteit de conditie verslechtert, waardoor beperkingen en de negatieve stemming toenemen, en uiteindelijk ook de pijn intenser wordt ervaren. Het vreesvermijdingsmodel is vooral getoetst bij patiënten met chronische rugpijn. Patiënten die pijn meer catastroferen en angstiger zijn om bijvoorbeeld schade aan hun lichaam op te lopen, blijken minder bereid om lichamelijke inspanningstaken in het laboratorium uit te voeren, zoals het tillen van een tas, het maken van strekbewegingen van het been onder belasting. Deze verminderde inspanning is onafhankelijk van de hoeveelheid pijn die wordt gerapporteerd (Al-Obaidi, Nelson, Al-Awadhi, \& Al-Shuwaie, 2000; Geisser, Haig, \& Theisen, 2000; Goubert, Crombez, \& Danneels, 2005; Swinkels-Meewisse et al., 2006; Vlaeyen et al., I995; zie voor een overzicht Leeuw et al., 2007). Wanneer de vermijding langdurig wordt volgehouden kan dit leiden tot verdergaande lichamelijke beperkingen. Correlationele studies laten zien dat er een samenhang is tussen catastroferen van pijn, angst voor pijn, en ervaren beperkingen in het dagelijkse leven van patiënten met chronische pijnklachten (Peters, Vlaeyen, \& Weber, 2005; Sullivan et al., 2005; Turner, Mancl, \& Aaron, 2004). Correlaties zeggen echter niets over causaliteit en daarom voerden Sullivan en collega's een interessant experiment uit (Sullivan et al., 2002). Zij onderzochten de voorspellende waarde van pijn catastroferen voor objectief vastgestelde vermijding van activiteiten. Het belangwekkende aan dit experiment is dat catastroferende gedachten over pijn gemeten werden voordat de deelnemers klachten hadden; hiermee kan worden uitgesloten dat de mate van pijn of de mate van ervaren beperkingen het niveau van catastroferen bepaalt. Vijftig studenten die in het dagelijks leven lichamelijk weinig actief waren, werden onderworpen aan een eenmalige intensieve krachttraining, bestaande uit 5 verschillende veelgebruikte excentrische en concentrische spierkrachtoefeningen. Zo'n oefenprogramma leidt in ongetrainde mensen na I tot 2 dagen 
tot aanzienlijke spierpijn. Twee dagen na de eerste oefensessie kwamen de deelnemers terug voor een identieke oefensessie. Zoals verwacht was er een toename in pijn na de eerste trainingssessie en werd er in de tweede sessie significant minder gewicht getild door de deelnemers. De belangrijkste bevinding van de studie was dat het pijn catastroferen (gemeten voor de eerste trainingssessie) de afname in getild gewicht voorspelde. Studenten die meer catastrofeerden waren tijdens sessie 2 minder bereid om zich opnieuw aan het zware trainingsprotocol te onderwerpen. Dit verschil bleef bestaan als gecorrigeerd werd voor pijnintensiteit tijdens sessie 2 . Het onderzoek suggereert een causale relatie tussen catastroferen van pijn en een afname in fysieke activiteiten vanwege de pijn.

Tot nu toe hebben we ons beperkt tot intra-individuele processen. Een nog onaangeroerde kwestie is of de ervaring van pijn en pijngedrag beïnvloed kan worden door de sociale context. Pijn vindt immers bijna altijd plaats in een sociale context. Denk maar aan de situatie van onze bouwvakker. Zou deze man minder pijn hebben gehad als zijn collega's niet zo verschrikt waren toegesneld? Of stel dat hij de dag ervoor getuige was geweest van een vergelijkbaar ongeluk bij een collega die nauwelijks pijn had?

Pijn als sociaal signaal

De expressie van pijn heeft ongetwijfeld een overlevingsfunctie. Het geeft de leden van een groep het signaal dat de lichamelijke integriteit van de groepsleden wordt bedreigd (Williams, 2002). Volgens de evolutionaire hypothese zal pijnexpressie vooral plaatsvinden wanneer belangrijke leden van de groep al eerder pijn hebben getoond in vergelijkbare situaties. Bovendien wordt er meer pijn geuit in een veilige sociale omgeving. Immers, evolutionair gezien is het niet zo verstandig om zich kwetsbaar te tonen aan een vreemde die potentieel een vijand zou kunnen zijn.

Eerder hebben we gezien dat catastrofale interpretaties van pijn een belangrijke invloed uitoefenen op de pijnervaring. Deze invloed kan afhangen van de sociale context waarin pijn plaatsvindt. Volgens het zogenaamde 'model van communal coping' heeft catastroferen vooral een sociale functie: verbaal en non-verbaal pijngedrag lokt steun van anderen uit (Sullivan et al., 200I; Thorn et al., 2004). Dit model voorspelt dan ook dat alleen in een situatie waarin een of meer andere personen aanwezig zijn, er een verschil in pijnexpressie tussen hoog en laag catastroferende mensen te vinden is. Bewijs voor deze stelling werd gevonden in het volgende experiment (Sullivan, Adams, \& 
Sullivan, 2004). Studenten werden uitgenodigd mee te doen aan een ijswater-pijntest, waarbij de sociale context werd gemanipuleerd. Bij de helft van de proefpersonen was een observator aanwezig. De andere helft deed de taak alleen. De observator werd geïntroduceerd als een onderzoeksassistent die de temperatuur van het water moest controleren en die geen gesprek met de proefpersoon mocht aangaan. Voor de laag catastrofeerders maakte het geen verschil of de taak al dan niet in aanwezigheid van de observator werd uitgevoerd. Hoog catastrofeerders daarentegen rapporteerden meer pijn, en toonden meer pijnlijke gezichtsexpressies, in aanwezigheid van de observator vergeleken met de hoog catastroferende proefpersonen die de taak alleen uitvoerden.

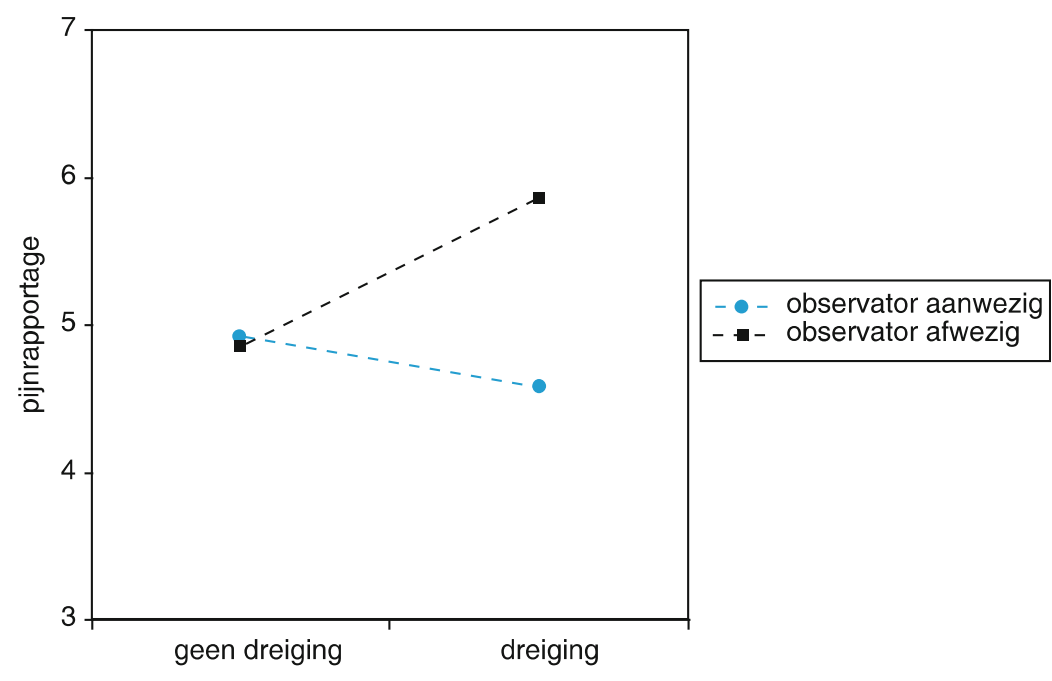

Figuur 11.4 Gerapporteerde pijn tijdens de ijswater-pijntest hangt af van hoe dreigend de instructies zijn en de aanwezigheid van een observator in de testruimte. Als er een andere persoon aanwezig is tijdens de test, wordt de versterkende invloed van dreiging op pijnrapportage tenietgedaan

Hoewel dit experiment aantoont dat de invloed van catastroferen op de pijnervaring kan afhangen van de sociale context, is er ook een andere verklaring mogelijk dan die van communal coping (Severeijns, Vlaeyen, \& Van den Hout, 2004). Er valt niet uit te sluiten dat de taak in aanwezigheid van de observator als meer bedreigend werd ervaren dan de taak zonder observator. De observator - met witte jas - had immers als taak ervoor te zorgen dat de temperatuur van het water op peil bleef. We besloten daarom tot een replicatie van de studie van Sullivan en collega's (Vlaeyen et al., 2009). In ons experiment werden de 'dreigwaarde' van de taak en de sociale context onafhankelijk van elkaar 
gemanipuleerd. In de dreigende conditie kregen deelnemers te horen dat de pijnlijke sensaties bij onderdompeling in ijswater de eerste tekenen van bevriezing waren. Bovendien gaven we ze valse feedback over hun bloeddruk, met de boodschap dat deze kantje boord was, net laag genoeg om geen schadelijke effecten van de test te ondervinden. De observator werd geïntroduceerd als een stagiaire van een andere universiteit, die een kijkje kwam nemen. Onze instructie was effectief: deelnemers ervoeren meer dreiging in de conditie met de bedreigende instructie. De aanwezigheid van een observator verminderde de dreigwaarde van de test, zowel in de conditie met als zonder dreiginstructies. Blijkbaar voelden deelnemers zich veiliger als er iemand aanwezig was, ook al had die iemand verder geen invloed op de test. Wat waren de gevolgen voor pijnrapportage? Zoals verwacht rapporteerden deelnemers meer pijn als instructies de test bedreigend maakten. Dit bleek echter alleen het geval als er geen observator aanwezig was. De aanwezigheid van een ander, deed het effect van dreiging volkomen teniet (figuur II.4). De conclusie van deze experimenten is dat de invloed van sociale context op pijn complex is, en mede afhangt van de dreiging die van een situatie uitgaat en de betekenis die aan de aanwezige ander(en) wordt toegekend.

\section{De sympathieke ander}

Wat gebeurt er als iemand getuige is van de pijn van een ander? Een van de eerste studies op het gebied van observationeel leren toont aan dat iemands pijntolerantie wordt beïnvloed door het zien van een model dat al dan niet controle over pijn heeft. In aanwezigheid van 'tolerante' modellen toonden proefpersonen ook meer tolerantie voor pijn dan in aanwezigheid van 'intolerante' modellen. Opmerkelijk was dat deze verschillen bleven bestaan, ook nadat de details van de experimentele manipulatie aan de proefpersonen waren onthuld. Dat suggereert dat modellen een krachtige invloed kunnen uitoefenen (Craig \& Best, 1977).

En wat gebeurt er als iemand beloond wordt na het uiten van pijn (bekrachtiging)? In feite gaat het hier om de invloed van de sociale context op pijn via operant leren. Een duidelijk voorbeeld is de aandacht en sympathie van belangrijke anderen die volgen op verbale of gedragsmatige uitingen van pijn. Indirect bewijs voor de rol van positieve bekrachtiging bij het in stand houden van pijngedrag komt uit onderzoek waarin patiënten met chronische pijn een taak uitvoeren of een pijninductieprocedure ondergaan terwijl de partner wel of niet aanwezig is (Block, I98I). Indien de partner een ondersteunende hou- 
ding heeft ten opzichte van de patiënt neemt het pijngedrag verbaal en non-verbaal toe, en bij een niet-ondersteunende partner neemt het pijngedrag af. Daarnaast hebben experimentele studies aangetoond dat verbale rapportage van pijn op constante nociceptieve prikkels zowel naar boven als naar beneden kan worden bijgesteld, afhankelijk van de feedback (goedkeuring of afkeuring) die op de rapportage volgt. Jolliffe en Nicholas (2004) stelden gezonde proefpersonen herhaaldelijk gedurende ro seconden bloot aan een pijnprikkel. De proefpersonen beoordeelden steeds de pijn. In de bekrachtigende conditie werd elke toename in pijnrapportage gevolgd door een verbale bekrachtiger, terwijl dit niet het geval was voor de controleconditie. Zoals verwacht nam de gerapporteerde pijn alleen toe in de bekrachtigende conditie. Opmerkelijk genoeg lijkt het naar boven bijstellen van de verbale pijnrespons door positieve bekrachtiging bij chronische pijnpatiënten minder snel uit te doven dan bij gezonde controles (Flor, Knost, \& Birbaumer, 2002).

\section{Therapie voor chronische pijn}

Er zijn op dit moment tal van niet-medische behandelingen voor patiënten met chronische pijn, zoals fysieke spiertraining, het aanleren van copingstrategieën, problem-solving-therapie, operante behandelingen en cognitieve therapie (Keefe et al., 2004). Wanneer deze behandelingen worden vergeleken met wachtlijstcontroles of andere niet-psychologische behandelingen, blijken ze slechts matig effect te hebben. En ook onderling verschillen de behandelingen maar weinig in effectiviteit (Morley, Eccleston, \& Williams, 1999). Recent werd de effectiviteit van een fysiek oefenprogramma, een cognitief-gedragsmatige behandeling, en de combinatie van beide met elkaar en met een wachtlijstgroep vergeleken. Alle drie de behandelingen deden het beter dan de wachtlijst, maar er waren geen verschillen tussen de drie actieve behandelingen (Smeets et al., 2008). Opvallend was echter dat de verbeteringen die de drie actieve behandelingen bewerkstelligden terug te voeren waren op hetzelfde mechanisme, namelijk een reductie in pijn catastroferen (Smeets, Vlaeyen, Kester, \& Knottnerus, 2006). Dit wordt vaker gemeld (Burns, Kubilus, Bruehl, Harden, \& Lofland, 2003; Spinhoven et al., 2004). De bevindingen suggereren dat gerichte en systematische verandering van catastrofale interpretaties van pijn minstens zo effectief - zo niet effectiever - is dan alles wat men voorts zou kunnen bedenken aan therapeutische interventies. Dit is overigens helemaal in lijn met de aanname van het eerder beschreven vreesvermijdingsmodel (Vlaeyen \& Linton, 2000). 
Een van de meest effectieve therapieën om catastrofale interpretaties van pijn, angst om te bewegen, en vermijdingsgedrag van patiënten met chronische pijnklachten in het bewegingsapparaat te reduceren is exposure in vivo in combinatie met gedragsexperimenten. Disfunctionele overtuigingen worden uitgedaagd en tijdens de exposure en gedragsexperimenten ervaren patiënten aan den lijve dat het achterwege laten van hun normale 'veiligheidsgedrag' niet leidt tot de verwachte catastrofe. Een aantal studies onderzocht de effecten hiervan bij patiënten met chronische pijnklachten die angstig waren voor het uitvoeren van bepaalde bewegingen. Een eerste studie beschrijft een herhaald single-case-experiment bij zes patiënten met chronische rugpijn, allen geselecteerd vanwege hun grote angst om te bewegen. Het experiment volgde de logica van een zogenaamd cross-overdesign, waarbij exposure in vivo werd vergeleken met de gebruikelijke oefentherapie. De patiënten beoordeelden de schadelijkheid van lichamelijke activiteiten aan de hand van een reeks foto's. Deze beoordelingen gebruikten de onderzoekers voor het maken van een angsthiërarchie. Drie patiënten kregen eerst de exposure en vervolgens de oefentherapie, terwijl aan de overige drie patiënten de omgekeerde volgorde werd aangeboden. De resultaten waren opmerkelijk. Vermindering van angst en gerapporteerde beperkingen werden alleen aangetroffen tijdens de exposurebehandeling, en niet tijdens de oefentherapie (Vlaeyen et al., 200I). In een daaropvolgend experiment werden de resultaten gerepliceerd. Toen werd bovendien gevonden dat de exposure ook gevolgen had voor de activiteit thuis. Met een activiteitenmeter die deelnemers gedurende I week voor en na behandeling op hun lichaam droegen kon nagegaan worden hoe actief de deelnemers waren. Exposure zorgde voor een markante toename in lichamelijke activiteit (Vlaeyen, De Jong, Geilen, Heuts, \& Van Breukelen, 2002).

Opvallend was de abrupte afname in de angst voor bewegen en het aantal ervaren beperkingen in beide experimenten. Mogelijk speelde de geruststellende informatie die patiënten ontvingen voorafgaande aan de daadwerkelijke exposuresessies hierin een rol. Daarom werd deze informatie in een vervolgstudie een aantal weken vóór de exposure aangeboden. Hieruit bleek dat de angst voor beweging en pijn inderdaad al afnam na het aanbieden van de informatie. De angst nam echter nog verder af tijdens de exposuresessies, terwijl de oefentherapie niet tot een verdere reductie in angst leidde. Ook de ervaren beperkingen werden minder na exposure, en dat werden zij niet tijdens de voorafgaande instructie, en evenmin tijdens de oefentherapie (De Jong et al., 2005). 
Ook twee grotere studies waarin exposure met oefentherapie werd vergeleken, bevestigden de bevindingen dat de exposure meer effectief is (Leeuw et al., 2008; Woods \& Asmundson, 2008). Exposure leidde tot een aanzienlijk grotere reductie in pijngerelateerde angst. Bovendien bleek dat de afname van ervaren beperkingen in het dagelijkse leven afhankelijk was van de mate waarin de waargenomen schadelijkheid van bewegingen was gereduceerd door de behandeling (Leeuw et al., 2008).

\section{De mens lijdt nog het meest ...}

We zagen dat de ervaring van pijn en pijngedrag worden beïnvloed door verwachtingen, de betekenis die aan de pijn wordt toegekend, angst, en de sociale context waarin de pijn plaatsvindt. Ook de bouwvakker waarmee dit hoofdstuk begon, is nu beter te begrijpen. Het zien verdwijnen van de spijker in de voet, en de veronderstelling dat deze de tenen doorboord heeft, is vanzelfsprekend een angstige ervaring die de verwachting van een lelijke wond en veel pijn opwekt. Het slachtoffer heeft mogelijkerwijze allerlei catastrofale gedachten over de gevolgen van zijn verwonding, zoals 'ik zal nooit meer goed kunnen lopen' en 'als ik niet kan lopen verlies ik mijn baan'. Deze negatieve gevoelens en gedachten versterken zijn gevoel van kwetsbaarheid en het uitbundige pijngedrag is mede een schreeuw om hulp aan zijn collega's, die hem ondanks hun drukke bezigheden meer aandacht schenken dan gebruikelijk. Als vervolgens blijkt dat de tenen ongeschonden zijn, dat ze op normale manier kunnen bewegen en dat hij er zonder probleem op kan steunen, verandert de betekenis van de situatie. Verwachtingen worden bijgesteld, de angst, en vervolgens ook de pijn, nemen geleidelijk af. De anekdote is een extreem voorbeeld van pijnervaring en pijnexpressie in afwezigheid van nociceptieve input.

Wat als er wel degelijk nociceptieve input aanwezig is? Ook dan oefenen psychologische en contextuele factoren een modulerende werking uit op pijnervaring en pijngedrag. Ook als er wel sprake van lichamelijke pathologie is, voorspelt pijn catastroferen pijn en de ervaren hinder in het dagelijks leven (Severeijns, Vlaeyen, Van den Hout, \& Weber, 200I). Het onderscheid tussen medisch verklaarde en onverklaarde pijn wordt niet meer zo relevant geacht, en cognitieve gedragstherapie biedt perspectieven voor de meeste patiënten met pijn, ongeacht hun medische diagnose: de mens lijdt nog het meest van het lijden dat hij vreest. 